\title{
TANGGUNG JAWAB PELAKU USAHA TERHADAP KONSUMEN (PENUMPANG) PESAWAT UDARA
}

\author{
TITIN TITAWATI ${ }^{1)}$, ALINE FEBRIYANI LOILEWEN ${ }^{2)}$, GDE TUSAN ARDIKA ${ }^{3)}$ \\ Program Studi Hukum K. Mataram UNMAS Denpasar \\ ${ }^{1)}$ titintitawati@gmail.com, ${ }^{2)}$ alinefebriyani@gmail.com
}

\begin{abstract}
ABSTRAK
Perkembangan di bidang pengangkutan baik itu barang maupun jasa, khususnya pengangkutan/ transportasi yang menggunakan sarana pesawat udara sangat pesat, dapat dilihat dengan banyaknya pelaku usaha yang bergerak di bidang usaha penerbangan. Namun hal tersebut tidak diimbangi dengan pelayanan yang baik terhadap konsumen, maskapai penerbangan akhir-akhir ini sering melakukan pembatalan penerbangan secara sepihak atau cancellation of flight dengan berbagai alasan. Hal ini menyebabkan kerugian bagi penumpang sebagai konsumen. Penelitian ini bertujuan untuk mengetahui bagaimana tanggung jawab pelaku usaha terhadap konsumen/ penumpang yang mengalami kerugian akibat pembatalan penerbangan dan upaya hukum yang dapat dilakukan oleh konsumen. Penelitian ini menggunakan bentuk penelitian hukum normative, yaitu penelitian yang didasarkan pada peraturan-peraturan dan perundang-undangan tertulis dan berbagai literature yang berhubungan dengan permasalahan yang akan dibahas dalam penelitian ini. Maskapai penerbangan sebagai pelaku usaha dapat dimintai pertanggungjawaban apabila melakukan kesalahan. Ada beberapa jenis tanggungjawab dalam hukum diantaranya adalah tanggungjawab dalam arti resposibility atau juga disebut tanggungjawab moral dan tanggungjawab dalam arti liability atau juga disebut tanggungjawab secara yuridis. Bentuk tanggungjawab maskapai penerbangan kepada penumpang termasuk ke dalam bentuk tanggungjawab berdasarkan unsur kesalahan (liabilitybased on fault) yang di dasarkan pada prinsip tanggungjawab mutlak (strict liability). Doktrin onrechtmatige daad sebagai landasan terbentuknya prinsip tanggungjawab mutlak yang tercantum pada pasal 1365 KUH Perdata yang menitik beratkan pada unsure kesalahan (fault).
\end{abstract}

Kata kunci: pelaku usaha/maskapai penerbangan, konsumen/penumpang, pembatalan penerbangan.

\section{ABSTRACT}

The development in the transportation sector, both goods, and services, especially transportation/ transportation using aircraft, is very rapid, it can be seen from the large number of business actors engaged in the aviation business. However, this is not balanced with good service to consumers, airlines have recently made unilateral flight cancellations or cancellations of flights for various reasons. This causes losses for passengers as consumers. This study aims to determine how the responsibility of business actors towards consumers/ passengers who suffer losses due to flight cancellations and legal remedies that can be taken by consumers. This study uses a form of normative legal research, which is research-based on written regulations and legislation and various literature related to the issues to be discussed in this study. An airline as a business actor can be held accountable if it makes a mistake. There are several types of responsibility in law, including responsibility in the sense of responsibility or also called moral responsibility, and responsibility in the sense of liability or also called juridical responsibility. The form of airline responsibility to passengers is included in the form of responsibility based on the element of error (liability based on fault) which is based on the principle of absolute responsibility (strict liability). The onrechtmatige daad doctrine is the basis for the formation of the principle of absolute responsibility as stated in article 1365 of the Civil Code which focuses on fault elements.

Keywords: business actors/airlines, consumers/passengers, flight cancellations 


\section{PENDAHULUAN}

Transportasi atau pengangkutan merupakan bidang yang sangat penting dalam kehidupan masyarakat Indonesia. Hal ini karena beberapa faktor antara lain, keadaan geografis negara Indonesia yang terdiri dari ribuan pulau kecil dan besar, perairan yang sebagian besar terdiri dari sebagian besar laut, sungai dan danau yang memungkinkan pengengkutan melalui darat, laut dan udaraguna menjangkau seluruh wilayah Indonesia.Selain itu, transportasi merupakan sarana untuk memperlancar roda perekonomian, membuka akses ke daerah pedalaman atau terpencil, menegakkan kedaulatan negara, serta mempengaruhi semua aspek kehidupan masyarakat.

Pentingnya transportasi tercermin pada semakin meningkatnya kebutuhan jasa angkutan bagi mobilitas orang serta barang di dalam negeri maupun luar negeri, serta berperan sebagai pendorong dan penggerak bagi pertumbuhan daerah dan pengembangan wilayah, sehingga wilayah terpencil sekalipun sekarang dapat dijangkau. Mengingat pentingnyakeberadaan pengangkutan di Indonesia, maka pembangunan dan peningkatan kualitas pelayanan pengangkutan sangat diperlukan. Pembangunan yang baik dan berkualitas tidak hanya mengenai mutu sarananya saja, juga harus menyangkut pembangunan berbagai aspek yang ada dalam pengangkutan itu sendiri, di antaranya aspek hukum.

Salah satu hal yang perlu diperhatikan dalam pembangunan hukum di bidang pengangkutan adalah terkait dengan tanggung jawab pengangkut/pelaku usaha terhadap konsumen penumpang pesawat udara, khususnya dalam hal terjadi pembatalan penerbanganyang menimbulkan kerugian bagi penumpang. Mengenai tanggung jawab pengangkut, E Saefullah Wiradipradja berpendapt,"(...) titik sentral setiap pembahasan mengenai tanggungjawab pengangkut pada umumnya terletak pada prinsip tanggungjawab (liability principle) yang diterapkan."

Adapun berdasarkan Undang-Undang Nomor 8 Tahun 1999 tentang Perlindungan Konsumen.Prinsip tentang tanggung jawab merupakan perihal yang sangat penting dalam hukum perlindungan konsumen. Dalam kasus pelanggaran hak konsumen, diperlukan kehati-hatian dalam menganalisis siapa yang harus bertanggung jawab dan seberapa jauh tanggung jawab dapat dibebankan kepada pihak terkait.

Menurut Abdul Kadir Muhammad, pengangkutan adalah sebagai proses kegiatan pemindahan penumpang dan/ atau barang dari suatu tempat ke tempat lain dengan menggunakan berbagai jenis alat pengangkut mekanik yang diakui dan diatur undang sesuai bidang angkutan dan kemajuan teknologi dalam kegiatan pengangkutan udara niaga terdapat dua pihak, yaitu pengangkut dalam hal ini adalah perusahaan atau maskapai penerbanganan pihak pengguna jasa atau konsumen. Para pihak tersebut terikat oleh suatu perjanjian, yaitu perjanjian pengangkutan. Sebagaimana kita ketahui bahwa perjanjian merupakan manisfestasi dari hubungan hukum yang bersifat keperdataan yang harus dipenuhi, yang biasa dikenal dengan istilah "prestasi". Adapun prestasi dalam hukum perjanjian adalah pelaksanaan dari isi perjanjian yang mana telah diperjanjikan dan menurut tata cara yang telah disepakati bersama.

Dalam hukum pengangkutan, kewajiban pengangkut antara lain mengangkut penumpang dan/atau barang dengan aman, utuh dan selamat sampai tujuan, memberikan pelayanan yang baik, mengganti kerugian penumpang sesuai dengan jadwal yang telah ditetapkan dan lain-lain.Sedangkan kewajiban penumpang adalah membayar ongkos pengangkutan yang besarnya telah ditentukan, menjaga barang-barang yang berada dibawah pengawasannya, melaporkan jenis-jenis barang yang dibawa terutama barang-barang yang berkategori berbahaya, mentaati ketentuan-ketentuan yang ditetapkan pengangkut yang berkenaan dengan pengangkutan. Hak dan kewajiban para pihak tersebut biasanya dituangkan dalam suatu dokumen perjanjian pengangkutan.

Ketentuan tentang pengangkutan juga berlaku didalam kegiatan pengangkutan atau transportasi udara dalam hal pengangkut atau maskapai penerbangan berkewajiban untuk mengangkut penumpang dengan aman dan selamat sampai tujuan secara tepat waktu, dan sebagai konpensasi dari pelaksanaan kewajibannya tersebut maka perusahaan penerbangan mendapatkan bayaran sebagai ongkos penyelenggaraan pengakutan dari penumpang. Namun, dalam praktik kegiatan transportasi udara niaga sering kali pengangkut atau maskapai penerbangan tidak memenuhi kewajibannya secara baik dan benar khususnya adanya pembatalan penerbangan penumpang pesawat secara sepihak.

Transportasi atau pengangkutan udara merupakan sarana perhubungan yang dianggap cepat, efisien, ekonomis dan nyaman.Berdasarkan Peraturan Menteri No. 32 Tahun 2015, Pengangkutan udara adalah setiap kegiatan dengan menggunakan pesawat udara untuk mengangkut penumpang, kargo, dan pos untuk suatu perjalanan atau lebih dari suatu bandar udara ke bandar udara yang lain atau beberapa bandar udara.Terjadinya pengangkutan melalui udara karena adanya perjanjian antara pihak pengangkut denga penumpang, berupa 
adanya dokumen pengangkutan atau tiket. Banyaknya pengangkutan udara dalam kurun waktu terakhir ini telah menciptakan iklim yang kompetitif antara satu maskapai penerbangan dengan lainnya, hal ini tidak memungkiri bahwa kualitas maskapai tersebut telah sesuai standart. Di dalam prakteknya, kegiatan pengangkutan udara tidak terlepas dari permasalahan, khususnya permasalahan yang dapat menimbulkan kerugian terhadap konsumen. Mulai dari kecelakaan pesawat, keterlambatan penerbangan, dan yang akhir-akhir ini sering terjadi adalah pembatalan penerbangan secara sepihak sehingga merugikan konsumen. Selain pembatalan penerbangan secara sepihak,konsumen/penumpang pesawat juga sering sekali mengeluhkan bahwa pelayanan pemberian informasi pembatalan, pelayanan yang diberikan tidak secara profesional. Kemudian mengenai pengembalian uang tiket (refund) seperti berbelit-belit dan tidak transparan, hal ini tentunya sangat merugikan konsumen.

\section{Rumusan Masalah.}

Adapun rumusan masalah adalah sebagai berikut:

1. Bagaimana tanggung jawab pelaku usaha terhadap kerugian konsumen atas pembatalan penerbangan?

2. Upaya hukum apa yang dapat dilakukan oleh konsumen atas pembatalan penerbangan?

\section{Tujuan Penelitian.}

Penelitian ini bertujuan untuk mengkaji dan menganalisis bagaimana tanggung jawab pelaku usaha berdasarkan Undang-Undang No.1 Tahun 2009 tentang Penerbangan dan dalam hal memberikan perlindungan konsumen jasa penerbangan.

\section{METODE PENELITIAN}

Penelitian ini merupakan penelitian kepustakaan yakni melakukan pengkajian terhadap berbagai referensi baik buku-buku ,literaur maupun peraturan perundang-undangan yang berkaitan dengan objek penelitian. Pendekatan yang digunakan adalah pendekatan normative yang memandang hukum sebagai seperangkat aturan dan kaidah yang bersifat normative. Teknik yang dgunakan dalam pengumpulan bahan hukum adalah dengan studi dokumen, yakni melakukan pengkajian terhadap data kepustakaan (data sekunder) yang relevan dengan objek penelitian, yang meliputi bahan hukum primer, sekunder dan tersier, baik terhadap peraturan perundang undangan, buku-buku, referensi maupun kasus-kasus hukum, selanjutnya dianalisis secara deskriptif kualitatif.

\section{HASIL DAN PEMBAHASAN}

\section{A. Tanggung Jawab Maskapai Penerbangan Atas Pembatalan Tiket Pesawat Penumpang}

Sejak covid 19 mewabah di dunia menyebabkan roda perekonomian terpuruk, tidak terkecuali imbasnya kepada perusahaan yang bergerak di bidang penerbangan. Situasi seperti ini menjadikan perusahaan penerbangan berlomba-lomba untuk menarik calon penumpang dengan berbagai macam cara, baik itu melalui harga tiket yang relative murah hingga pelayanan terbaik dari masing-masing perusahaan penerbangan .Namun, pada umumnya dalam pemberian pelayanan penerbangan terhadap penumpang sering terjadi hambatan yang bermacam-macam jenisnya, antara lain keterlambatan dan pembatalan penerbangan.

Pembatalan (cancelation of flight) dapat diartikan sebagai suatu penundaan keberangkatan ataupun pengalihan penerbangan dikarenakan sebab-sebab tertentu. Ketentuan mengenai keterlambatan serta pembatalan keberangkatan penumpang diatur dalam Undang-Undang Nomor 1 Tahun 2009 tentang Penerbangan diantaranya sebagai berikut:

Faktor penyebab pembatalan penerbangan adalah faktor niaga, faktor teknik, faktor operasi, faktor cuaca dan faktor bandara. Faktor niaga yang terjadi diantaranya karena proses boarding bermasalah dan kelebihan penumpang. Sedangkan faktor operasi diantaranya keterlambatan pilot dan jasa boga.

Faktor-faktor pembatalan penerbangan dapat berupa faktor teknis dan non teknis. Menurut Pasal 146 Undang-Undang Penerbangan dan Pasal 13 ayat (2) Peraturan Mentri Perhubungan Nomor 77 Tahun 2011 menyebutkan bahwa pembatalan penerbangan yang dikarenakan oleh faktor cuaca yaitu seperti hujan lebat, petir, badai, kabut, asap, jarak pandang dibawah standar maksimal yang mengganggu keselamatan penerbangan. Hal tersebut pembatalan penerbangan di luar dari teknis operasional.

Sedangkan menurut Pasal 146 Undang-Undang Penerbangan dan Pasal 13 ayat (3) Peraturan Menteri Perhubungan Nomor 77 Tahun 2011 pembatalan yangdikarenakan faktor Teknik Operasional, seperti : 
a. Bandar udara untuk keberangkatan dan tujuan tidak dapat digunakan operasional pesawat udara;

b. Lingkungan menuju bandar udara atau landasan terganggu fungsinya misalnya retak, banjir atau kebakaran;

c. Terjadinya antrian pesawat udara lepas landas, mendarat, atau alokasi waktu keberangkatan di bandar udara;

d. Keterlambatan pengisian bahan bakar;

Menurut penjelasan Pasal 146 Undang-Undang Penerbangan bahwa pembatalan penerbangan yang dikarenakan faktor yang tidak termasuk Teknis Operasional yaitu :

a. Keterlambatan pilot, co pilot dan awak kabin;

b. Keterlambatan jasa boga (catering);

c. Keterlambatan penanganan di darat; Menunggu penumpang, baik yang baru melapor(checkin),pindah pesawat (transfer) atau penerbangan lanjutan (connecting flight); dan

d. Ketidaksiapan pesawat udara;

Dalam hal terjadi pembatalan penerbangan, pengangkut mempunyai kewajiban sebagaimana Pasal 12

Peraturan Menteri Perhubungan Nomor 77 Tahun 2011 tentang Tanggung Jawab Pengangkut Angkutan Udara yaitu :

1) Dalam hal teijadi pembatalan penerbangan sebagaimana dimaksud dalam Pasal 9 huruf c, pengangkut wajib memberitahukan kepada penumpang paling lambat 7 (tujuh) hari kalender sebelum pelaksanaan penerbangan;

2) Pembatalan penerbangan sebagaimana dimaksud pada ayat (1), pengangkut wajib mengembalikan seluruh uang tiket yang telah dibayarkan oleh penumpang;

3) Pembatalan penerbangan yang dilakukan kurang dari 7 (tujuh) hari kalender sampai dengan waktu keberangkatan yang telah ditetapkan, berlaku ketentuan Pasal 10 huruf b dan c;

Pemberitahuan mengenai pembatalan penerbangan berdasarkan ketentuan Pasal 10 huruf b dan c yang dilakukan kurang dari 7 (tujuh) hari kalender sampai dengan waktu keberangkatan yang telah ditetapkan, maka penumpang berhak mendapatkan ganti kerugian sebagai berikut:

a) Diberikan ganti kerugian sebesar $50 \%$ (lima puluh persen) dari Rp. 300.000,00. (tiga ratus ribu rupiah) apabila pengangkut menawarkan tempat tujuan lain yang terdekat dengan tujuan penerbangan akhir penumpang (re- routing), dan pengangkut wajib menyediakan tiket penerbangan lanjutan atau menyediakan transportasi lain sampai ke tempat tujuan apabila tidak ada moda transportasi selain angkutan udara;

b) Dalam hal dialihkan kepada penerbangan berikutnya atau penerbangan milik Badan Usaha Niaga Beijadwal lain, penumpang dibebaskan dari biaya tambahan, termasuk peningkatan kelas pelayanan atau apabila terjadi penurunan kelas atau sub kelas pelayanan, maka terhadap penumpang wajib diberikan sisa uang kelebihan dari tiket yang dibeli;

Perlu diperhatikan bahwa menurut Pasal 12 ayat (4) Peraturan Menteri Perhubungan Nomor 77 Tahun 2011 tentang Tanggung Jawab Pengangkut Angkutan Udara menentukan bahwa pembatalan penerbangan sebagaimana dimaksud di atas berlaku apabila badan usaha angkutan udara niaga berjadwal melakukan perubahan jadwal penerbangan. Oleh karena itu, dalam hal pembatalan penerbangan maka yang sekarang berlaku adalah ketentuan Pasal 36 huruf $d$ dan huruf e Peraturan Menteri Perhubungan Nomor 25 Tahun 2008 tentangPenyelanggaraan Angkutan Udara yaitu:

a. Apabila terjadi pembatalan penerbangan, maka perusahaan angkutan udara niaga beijadwal wajib mengalihkan penumpang ke penerbangan berikutya dan apabila penumpang tersebut tidak dapat dipindahkan ke penerbangan berikutnya atau ke perusahaan angkutan udara niaga beijadwal lainnya, maka kepada penumpang tersebut wajib diberikan fasilitas akomodasi untuk dapat diangkut pada penerbangan hari berikutnya;

b. Apabila dalam hal keterlambatan sebagaimana tercantum dalam huruf b dan c, serta pembatalan sebagaimana tercantum dalam huruf d, penumpang tidak mau terbang/menolak diterbangkan, maka perusahaan angkutan udara niaga beijadwal harus mengembalikan harga tiket yang telah dibayarkan kepada perusahaan;

Ketentuan peralihan dari Peraturan Menteri Perhubungan Nomor 77 Tahun 2011 tidak menyatakan tidak berlakunya Peraturan Menteri Perhubungan Nomor 25 Tahun 2008, sehingga keduanya tetap berlaku.Dalam beberapa kondisi sebagaimana tersebut di atas, penumpang berhak dipindahkan ke penerbangan lain (mendapat tiket penerbangan lain), selain mendapatkan makanan dan minuman atau harus mengembalikan harga tiket yang telah dibayarkan kepada perusahaan.

Berdasarkan Undang-Undang perlindungan konsumen, tanggung jawab maskapai penerbangan terhadap konsumen penumpang pesawat udara adalah maskapai penerbangan selaku pelaku usaha mempunyai kewajiban 
terhadap konsumen penumpang pesawat udara . Menurut Pasal 7 Undang-Undang Republik Indonesia Nomor 8 Tahun 1999 tentang Perlindungan Konsumen, Kewajiban pelaku usaha adalah sebagai berikut:

1. Beritikad baik dalam melakukan kegiatan usahanya

2. Memberikan informasi yang benar, jelas, dan jujur mengenai kondisi dan jaminan barang dan/atau jasa serta memberi penjelasan penggunaan, perbaikan, dan pemeliharaan

3. Memperlakukan atau melayani konsumen secara benar dan jujur serta tidak diskriminatif

4. Menjamin mutu barang dan/atau jasa yang diproduksi dan/atau diperdagangkan berdasarkan ketentuan standar mutu barang dan/atau jasa yang berlaku

5. Memberi kesempatan kepada konsumen untuk menguji, dan/atau mencoba barang dan/atau jasa tertentu serta memberi jaminan dan/atau garansi atas barang yang dibuat dan/atau yang diperdagangkan

6. Memberi kompensasi, ganti rugi, dan/atau penggantian atas kerugian akibat penggunaan, pemakaian, dan pemanfaatan barang dan/atau jasa yang diperdagangkan

7. Memberi kompensasi, ganti rugi, dan/atau penggantian apabila barang dan/atau jasa yang diterima atau dimanfaatkan tidak sesuai dengan perjanjian.

Di samping adanya kewajiban yang perlu diperhatikan oleh pelaku usaha disini yaitu tanggung jawab yang merupakan bagian dari kewajiban yang mengikat kegiatan mereka dalam berusaha.Tanggung jawab ini disebut juga dengan istilah tanggung gugat produk (product liability). Product liability adalah suatu tanggung jawab secara hukum dari orang atau badan yang menghasilkan suatu produk (producer, manufacturer), dari orang atau badan yang bergerak dalam suatu proses untuk menghasilkan suatu produk (processor, assembler) atau mendistribusikan (seller, distributor) produk tersebut.

Undang-Undang Perlindungan Konsumen tidak mengatur secara jelas dan tegas soal jenis barang yang secara hukum dapat dipertanggungjawabkan dan sampai sejauhmana pertanggungjawaban atas barang tertentu dapat dikenakan bagi pelaku usaha atas hubungan hukumnya dengan konsumen.Penerapan konsep product liability ternyata tidak mudah.Sebab dalam sistem pertanggungjawaban secara konvensional, tanggung jawab produk didasarkan adanya wanprestasi (default) dan perbuatan melawan hukum (fault).

Berdasarkan Undang-Undang Nomor 1 Tahun 2009 tentang Penerbangan, mengenai perlindungan hukum bagi konsumen jasa angkutan udara, meskipun khusus dibatasi untuk penumpang bukanlah suatu hal yang mudah. Unsur-unsur perlindungan yang menjadi hak konsumen jasa angkutan dan keseluruhan pengaturan mengenai unsur-unsur itulah yang merupakan perlindungan hukum bagi konsumen yang kalau disusun secara sistematis dan integral akan merupakan suatu sistem perlindungan hukum bagi konsumen jasa angkutan udara.

Dalam suatu sistem perlindungan hukum bagi konsumen jasa angkutan udara adalah kepentingan konsumen karena konsumenlah yang menjadi tolok ukur bagi seluruh kegiatan angkutan udara.Tanpa konsumen tidak ada justifikasi bagi investasi untuk sarana dan prasarana angkutan udara yang begitu besar.Namun hal ini agaknya seringkali dilupakan. Pentingnya konsumen pasti akan lebih dirasakan oleh produsen jasa angkutan udara kalau industri angkutan udara telah mempunyai saingan dalam tubuh industri, kalau bagi konsumen jasa angkutan udara tersedia pilihan antara beberapa perusahaan angkutan udara yang sama baiknya, baik dari segi peralatan,maupun pelayanan.

Suatu sistem perlindungan hukum bagi konsumen jasa angkutan udara adalah suatu sistem yang terdiri dari peraturan perundang-undangan dan prosedur yang mengatur semua aspek yang baik langsung maupun tidak langsung mengenai kepentingan dari konsumen jasa angkutan udara.

Dari sistem perlindungan hukum tersebut dapat dilihat unsur-unsur perlindungan konsumen, yaitu :

1. Keselamatan penerbangan

2. Keamanan penerbangan

3. Kenyamanan penerbangan

4. Pelayanan penerbangan

5. Pertarifan

6. Perjanjian angkutan udara

Dalam Pasal 179 Undang-Undang Republik Indonesia Nomor 1 Tahun 2009 diatur kewajiban asuransi penerbangan tanggung jawab hukum. Menurut Pasal tersebut pengangkut wajib mengasuransikan tanggung jawabnya atas kerugian penumpang yang meninggal dunia, cacat tetap, atau luka-luka yang diakibatkan eksiden angkutan udara di dalam pesawat dan/atau naik turun dari pesawat udara, bagasi tercatat hilang, musnah, atau rusak yang diakibatkan oleh kegiatan angkutan udara selama bagasi tercatat berada dalam pengawasan pengangkut, keterlambatan pada kargo yang dikirim hilang, musnah atau rusak yang diakibatkan oleh kegiatan angkutan udara selama kargo berada dalam pengawasan pengangkut. Besarnya pertanggungan asuransi 
untuk penumpang yang meninggal dunia, cacat tetap, atau luka-luka, sekurang-kurangnya harus sama dengan jumlah ganti kerugian yang diberikan oleh badan usaha angkutan udara niaga di luar ganti kerugian yang diberikan oleh lembaga asuransi yang ditetapkan oleh pemerintah, dan untuk bagasi kabin yang hilang atau rusak sekurang-kurangnya sebesar kerugian nyata, untuk bagasi tercatat dan kargo yang dikirim, sedangkan untuk keterlambatan berdasarkan kerugian penumpang, pengirim barang akibat keterlambatan. Dalam penjelasannya yang dimaksud sekurang-kurangnya dalam ketentuan ini adalah tanggung jawab ganti kerugian yang harus diberikan oleh pengangkut tidak boleh kurang dari yang ditetapkan oleh Menteri Perhubungan, tetapi penumpang dapat menuntut ganti kerugian yang lebih tinggi apabila dapat membuktikan kecelakaan yang terjadi disebabkan oleh kelalaian atau kesalahan pengangkut.

Dalam Pasal 180 Undang-Undang Republik Indonesia Nomor 1 Tahun 2009 diatur besarnya asuransi penerbangan. Menurut Pasal tersebut besarnya kewajiban mengasuransi adalah kecuali penumpang membuat perjanjian khusus yang menetapkan ganti kerugian yang lebih tinggi, sebesar tanggung jawab hukum dalam hal penumpang yang meninggal dunia, cacat tetap atau luka-luka, sedangkan jumlah ganti kerugian bagasi setinggitingginya kerugian nyata. Jumlah ganti kerugian tersebut di luar jumlah ganti kerugian yang diberikan oleh lembaga yang ditetapkan oleh pemerintah, dalam hal ini Jasa Raharja.Besarnya ganti kerugian tersebut diatur lebih lanjut dengan Peraturan Menteri Perhubungan. Menurut Pasal 240 Undang-Undang Republik Indonesia Nomor 1 Tahun 2009, badan usaha bandar udara bertanggung jawab terhadap kerugian yang diderita oleh pengguna jasa bandar udara dan/atau pihak ketiga yang diakibatkan oleh pengoperasian bandar udara. Tanggung jawab terhadap kerugian tersebut meliputi kematian atau luka fisik orang, musnah, hilang, atau rusak peralatan yang dioperasikan dan/atau dampak lingkungan di sekitar bandar udara akibat pengoperasian bandar udara wajib diasuransikan.Terhadap orang melanggar kewajiban mengasuransikan tanggung jawab hukumnya dikenakan sanksi administratif berupa peringatan, pembekuan sertifikat, dan/atau pencabutan sertifikat.

\section{B. Upaya Hukum Konsumen Penumpang Pesawat Udara atas Pembatalan Penerbangan.}

Sebagai pengguna barang/jasa, konsumen memiliki sejumlah hak dan kewajiban. Pengetahuan tentang hak-hak konsumen sangat penting agar orang bisa bertindak sebagai konsumen yang kritis dan mandiri. Tujuannya, jika ditengarai adanya tindakan yang tidak adil terhadap dirinya, ia secara spontan menyadari akan hal itu. Konsumen kemudian bisa bertindak lebih jauh untuk memperjuangkan hak-haknya. Dengan kata lain, ia tidak hanya tinggal diam saja ketika menyadari bahwa hak-haknya telah dilanggar pelaku usaha.

Pembatalan penerbangan yang akhir-akhir ini sering dilakukan oleh pelaku usaha/perusahaan penerbangan sangat merugikan konsumen penumpang pesawat udara, sementara uang tiket penumpang tidak dapat dikembalikan secara langsung dan penumpang pesawat udara tersebut tidak dapat terbang ke tempat tujuannya sehingga harus membeli tiket maskapai penerbangan lain untuk mencapai tempat tujuannnya.

Sebagian konsumen merasa prosedur penyelesaian yang ditetapkan pihak perusahaan maskapai penerbangan tidak sebagaimana mestinya, petugas sering mengulur waktu, dan konsumen memerlukan waktu yang lama untuk mendapatkan haknya (dalam hal pengembalian uang tiket)..Apabila konsumen/penumpang merasa dirugikan akibat keterlambatan atau pembatalan penerbangan, maka yang bersangkutan dapat mengajukan tuntutan gugatan ganti kerugian terhadap perusahaan pengangkutan udara.

Adapun persyaratan dan tata cara pengajuan tuntutan ganti kerugian diatur dalam Peraturan Mentri Perhubungan Nomor 77 Tahun 2011 tentang Tanggung Jawab Pengangkut Angkutan Udara. Pengajuan gugatan ganti rugi kepada perusahaan pengangkut udara oleh konsumen yang dirugikan dimungkinkan oleh pasal 23 Peraturan Mentri Perhubungan Nomer 77 Tahun Tanggung Jawab Pengangkut Angkutan Udara, yang menyatakan :

"Besaran ganti kerugian yang diatur dalam peraturan ini tidak menutup kesempatan kepada penumpang, ahli waris, penerima kargo, atau pihak ketiga untuk menurut pengangkut ke pengadilan negeri di dalam wilayah Negara Kesatuan Republik Indonesia atau melalui arbitrase atau alternatif penyelesaian sengketa lain sesuai ketentuan peraturan perundang-undangan". Menurut serta pihak ketiga yang mengalami kerugian sebagaimana dimaksud dalam Pasal 2 hanya dapat dilakukan berdasarkan bukti sebagai berikut :

a. Dokumen terkait yang membuktikan sebagai ahli waris sesuai dengan ketentuan peraturan perundangundangan yang berlaku, tiket, bukti bagasi tercatat (claim tag) atau surat muatan udara (airway bill) atau bukti lain yang mendukung dan dapat dipertanggungjawabkan;

b. Surat keterangan dari pihak yang berwenang mengeluarkan bukti telah terjadinya kerugian jiwa dan raga/atau harta benda terhadap pihak ketiga yang mengalami kerugian akibat pengoperasian pesawat udara;

Pemberian ganti kerugian sebagaimana dimaksud diajukan kepada pengaturan yang secara nyata 
melakukan pengangkutan udara, apabila pengangkutan udara tersebut dilakukan lebih dari satu Badan Usaha Angkutan Udara. Sedangkan penyelesaian sengketa diatur Pasal 23 dan 24 Peraturan Mentri Perhubungan Nomer 77 tahun 2011 tentang Tanggung Jawab Pengangkut Angkutan Udara, yaitu :

Pasal 23 besaran ganti kerugian yang diatur dalam peraturan ini tidak menutup kesempatan kepada penumpang, ahli waris, penerima kargo, atau pihak ketiga untuk pengangkut ke pengadilan negeri di dalam wilayah Negara Kesatuan Republik Indonesia atau melalui arbitase atau alternatif penyelesaian sengketa lain peraturan perundang-undangan. Pasal 24 penyelesaian masalah pembuktian sebagaimana dimaksud dalam pasal 19 dapat diselesaikan melalui arbitrase atau alternatif sengketa lain sesuai ketentuan peraturan perundangundangan. Prosedur penyelesaian pengaduan konsumen yang ditempuh pihak perusahaan maskapai penerbangan tersebut sesuai dengan ketentuan penyelesaian sengketa yang diatur Undang-Undang Nomor 8 tahun 1999 tentang Perlindungan Konsumen, terutama Pasal 45 ayat (2) yang berbunyi penyelesaian sengketa konsumen dapat ditempuh melalui pengadilan atau diluar pengadilan berdasarkan pilihan sukarela para pihak yang bersengketa.

Kelalaian (wanprestasi) dari pihak perusahaan maskapai penerbangan dapat merugikan konsumen, sehingga apabila tidak ada tanggung jawab dalam penyelesaian dari pihak perusahaan maskapai penerbangan maka konsumen dapat mengadukan permasalahannya ke Lembaga Perlindungan Komsumen. Dalam ketentuan umum UUPK yang dimaksud dengan lembaga perlindungan konsumen swadaya masyarakat adalah lembaga non pemerintah yang terdaftar dan diakui oleh pemerintah yang mempunyai kegiatan menangani perlindungan konsumen.

Ketika konsumen datang untuk mengadukan masalahnya, biasanya pihak LPK akan memberikan saran dan masukan yang dapat dilakukan oleh konsumen untuk mempertahankan haknya. Jika konsumen merasa mampu untuk menyelesaikan sendiri masalahnya dengan pelaku usaha, maka dipersilahkan untuk menyelesaikannya sendiri. Namun jika konsumen memutuskan untuk melakukan pengaduan resmi melalui LPK, maka konsumen tersebut harus menandatangani surat kuasa kepada LPK, dan kemudian LPK yang akan menandatangani pengaduan tersebut.

Langkah yang diambil oleh Lpk adalah jalur non litigasi, jika tidak berhasil selanjutnya dilakukan jalur litigasi dengan persetujuan dari konsumen, yaitu sebagai berikut:

(1)Negosiasi yaitu proses tawar menawar dengan jalan berunding guna mencapai kesepakatan bersama antara para pihak;

(2)Mediasi tersebut yaitu negosiasi yang dilakukan oleh pihak ketiga, pihak ketiga tersebut membantu menyelesaikan sengketa tersebut; dan

(3)Konsiliasi yaitu suatu proses dengan mana setiap pihak mereka sendiri bertemu memberikan beberapa penyelesaian, lalu diajukan kepada pihak-pihak yang bersengketa untuk mendapatkan persetujuan;

Apabila terdapat pengaduan konsumen perusahaan maskapai penerbangan ke LPK, maka pihak LPK terlebih memberikan saran agar konsumen langsung menyelesaikan masalah sengketa dengan jalan keluar yang terbaik bagi kedua belah pihak secara damai dan kekeluargaan. LPK berperan memberikan saran atau masukan mengenai cara-cara yang harus diambil oleh konsumen/pelanggan untuk mendapatkan hak-hak mereka. Apabila cara tersebut tidak berhasil, maka LPK akan menempuh jalan mediasi untuk menyelesaikan sengketa/permasalahan tersebut, apabila penyelesaian sengketa melalui jalur litigasi tersebut melalui jalur litigasi. Adapun gugatannya dapat menggunakan ketentuan dalam Pasal 1365 Kitab Undang-Undang Hukum Perdata menyatakan :

"Setiap perbuatan yang melawan hukum yang membawakerugiankepadaseoranglain mewajibakan orang karena salahnya menerbitkan kerugian ini mengganti kerugian tersebut."

Konsumen penumpang pesawat udara yang merasa dirugikan terkait pembatalan penerbangan yang dilakukan oleh perusahaan penerbangan dapat mengadukannya kepada Lembaga Perlindungan Konsumen (LPK) dan melakukan penyelesaian sengketa diluar pengadilan atau menuntut ganti rugi terhadap pihak perusahaan penerbangan ke pengadilan negri setempat karena mengacu pada prinsip tanggung jawab atas dasar kesalahan untuk menentukan tanggung jawab pengangkut, karena dalam ajaran prinsip tanggung jawab pengangkutan di dasarkan pada pandangan bahwa yang membuktikan kesalahan pengangkut adalah pihak yang dirugikan dimungkinkan oleh Pasal 23 Peraturan Mentri Perhubungan Nomor 77 Tahun 2011 tentang Tanggung Jawab Pengangkutan Angkutan Udara. Selain itu, pemerintah perlu meninjau kembali terhadap instrumeninstrumen yang mengatur tentang kegiatan penerbangan, sarana dan prasarana serta fasilitas seluruh maskapai penerbangan di indonesia ke arah yang lebih baik agar penundaan bahkan pembatalan penerbangan bisa diminimalisir. 


\section{PENUTUP}

\section{Simpulan}

1. Tanggung jawab Maskapai Penerbangan atas Pembatalan tiket pesawat penumpang yaitu dalam hal terjadinya pembatalan, penerbangan wajib memberitahukan kepada penumpang mengenai pembatalan tersebut dan mengalihkan kepada penumpang lain sedangkan dalam hal penumpang menolak diterbangkan maka pihak pengangkut udara mengembalikan uang tiket yang telah dibayarkan sesuai dengan ketentuan yang diatur dalam Pasal 36 Huruf D Dan Huruf E Peraturn Mentri Perhubungan Nomor 25 Tahun 2008 tentang Penyelenggaraan Angkutan Udara karena dalam Peraturan Menteri Perhubungan Nomor 77 Tahun 2011 tentang Tanggung Jawab Pengangkut Angkutan Udara hanya niaga berjadwal melakukan perubahan jadwal penerbangan.

2. Upaya hukum konsumen penumpang pesawat atas pembatalan penerbangan yaitu Pasal 23 Peraturan Menteri Perhubungan Nomor 77 Tahun 2011 tentang Tanggung Jawab Pengangkut Angkutan Udara Konsumen yang dirugikan juga dapat mengajukan gugatan ganti kerugian ke pengadilan negeri setempat atau melalui arbitrase atau alternative penyelesaian sengketa lainnya.

\section{Saran}

1. Maskapai harus bertanggung jawab kepada konsumen jika adanya pembatalan penerbangan atau pengangkutan barang sesuai jadwal yang sudah di tentukan sebelum pembatalan.

2. Konsumen yang dirugikan dapat mengajukan gugatan ganti kerugian ke pengadilan negeri setempat atau melalui arbitrase atau alternative penyelesaian sengketa lainnya.

\section{DAFTAR PUSTAKA}

Ahmadi Miru. (2011). Prinsip-Prinsip Perlindungan Hukum Bagi Konsumen di Indonesia. Jakarta: Rajawali Pers Celina Tri Siwi Kristiyanti. (2011). Hukum Perlindungan Konsumen. Jakarta: Sinar Grafika

Dipenogoro Law Review, Volume 5, Nomor 2, Tahun 2016

E. Saefullah Wiradipradja. (2006). Tanggung Jawab Perusahaan Penerbangan Terhadap Penumpang Menurut

Hukum Udara Indonesia, Jakarta: Jurnal Hukum Bisnis Vol. 25.

Happy Susanto. (2008). Hak-Hak Konsumen Jika Dirugikan. Jakarta: Visi Media.

H.K. Martono. (2011) Hukum Angkutan Udara Berdasarkan UU RI No.1 Tahun 2009 Bagian Pertama. Jakarta:

Raja Grafindo Persada

Ronny Hanitijo Soemitro. (1985). Metode Penelitian Hukum dan Jurimetri. Jakarta: Ghalia Indonesia

Undang-Undang Nomor.1 Tahun 2009 tentang Penerbangan.

Undang-Undang Republik Indonesia Nomor 8 Tahun 1999 tentang Perlindungan Konsumen

Peraturan Mentri Perhubungan Nomor 25 Tahun 2008 tentang Penyelenggaraan Angkutan Udara

Peraturan Mentri Perhubungan Nomor 77 Tahun 2011 tentang Tanggung Jawab Pengangkut Angkutan Udara.

Website : http://www.ejournal-s1.undip.ac.id/index.php/dlr/ 